\title{
PENGARUH TEKNIK PENYELUBUNGAN BUAH KAKAO DENGAN PLASTIK TERHADAP SERANGAN HAMA Helopeltis sp.
}

\author{
Rizqi Widasaranti, F.X. Susilo \& Indriyati \\ Jurusan Agroteknologi Fakultas Pertanian Universitas Lampung \\ Jl. Prof. Dr. Soemantri Brodjonegoro No. 1 Bandar Lampung 35145
}

\begin{abstract}
ABSTRAK
Salah satu permasalahan pada produksi kakao di Indonesia adalah rusaknya buah akibat serangan hama Helopeltis sp. Serangan Helopeltis sp. dapat menurunkan produksi kakao hingga 50\%. Penelitian ini bertujuan untuk mengetahui efektivitas penyelubungan buah kakao menggunakan kantung plastik yang berbeda ukuran terhadap serangan hama Helopeltis sp. Penelitian ini dilaksanakan di kebun rakyat di Desa Way Laga Kecamatan Panjang Bandar Lampung pada bulan April September 2014. Perlakuan terdiri atas penyelubungan buah dengan kantung plastik berukuran sedang $(30 \mathrm{~cm} \times 15 \mathrm{~cm}, \mathrm{P} 1)$, penyelubungan buah dengan kantung plastik berukuran besar $(35 \mathrm{~cm}$ x $20 \mathrm{~cm}, \mathrm{P} 2)$, dan tanpa penyelubungan buah atau kontrol (P0), dengan 30 ulangan. Hasil penelitian menunjukkan bahwa penyelubungan buah kakao menggunakan kantung plastik efektif mengurangi keterjadian dan keparahan serangan Helopeltis sp. Namun efektivitas penggunaan kantung plastik berukuran relatif besar $(35 \mathrm{~cm} \times 20 \mathrm{~cm})$ tampak tidak berbeda dengan efektivitas penggunaan kantung plastik berukuran sedang $(30 \mathrm{~cm} \times 15 \mathrm{~cm})$.
\end{abstract}

Kata kunci: Helopeltis sp., kakao, kantung plastik

\section{PENDAHULUAN}

Kakao (Theobroma cacao Linnaeus) merupakan salah satu komoditas andalan perkebunan yang memegang peranan cukup penting dalam perekonomian Indonesia.Kakao menjadi salah satu sumber pendapatan dan penyumbang devisa ketiga dari sub sektor perkebunan dengan nilai sebesar US \$ 201 juta. Selain itu, perkebunan kakao juga dapat menyediakan lapangan pekerjaan dan mendorong perkembangan agribisnis dan agroindustri (Dhalimi, 2012).

Perkembangan perkebunan kakao di Indonesia dilakukan dalam bentuk perluasan areal. Pada tahun 2011 luas areal tanaman kakao telah mencapai 1,745,789 ha. Sebagian besar perkebunan kakao $(87,4 \%)$ dikelola oleh rakyat, sedangkan $6,0 \%$ merupakan perkebunan besar negara, dan $6,7 \%$ merupakan perkebunan besar swasta (Dhalimi, 2012).

Salah satu hambatan pada budidaya tanaman kakao yang menyebabkan produksinya menurun adalahserangan hama. Salah satunya Helopeltis sp. atau kepik penghisap buah kakao. Hama ini merupakan hama penting kedua setelah penggerek buah kakao (PBK). Menurut Indriani (2004 dalam Nurmansyah, 2011), serangan Helopeltis sp. pada tanaman kakao dapat menurunkan produksi hingga $50 \%$ dan meningkatkan biaya produksi hingga $40 \%$.

Pengendalian hama pada tanaman kakao pada umumnya masih menggunakan insektisida kimiawi. Namun penggunaan insektisida ini dapat menyebabkan timbulnya resistensi hama dan munculnya hama sekunder. Selain itu, residu insektisida dapat mencemari lingkungan dan dapat menyebabkan ditolaknya produk tersebut di pasaran(Siswanto dan Karmawati, 2012).

Alternatif lain untuk mengendalikan hama penghisap buah kakao adalah secara mekanik, misalnya dengan melakukan penyelubungan buah muda (Mustafa, 2005). Penyelubungan buah kakao muda ini dapat dilakukan dengan menggunakan kantung plastik transparan. Penyelubungan buah dapat mencegah hama Helopeltis sp. menusukkan alat mulutnya dan menghisap buah kakao.

Namun ukuran kantung plastik yang digunakan sebagai penyelubung buah perlu dicermati.Agar penyelubungan efektif, kantung plastik yang digunakan hendaknya cukup besar sehingga dapat menyelubungi seluruh buah kakao.Oleh karena itu, perlu dilakukan uji terhadap ukuran kantung plastik penyelubung yang digunakan.Penelitian ini bertujuan untuk mengetahui efektivitas penyelubungan buah kakaomenggunakan 
kantung plastik yang berbeda ukuran terhadap seranganhama Helopeltis sp.

\section{BAHAN DAN METODE}

Penelitian ini dilaksanakan pada bulan April sampai September 2014 di kebun rakyat di Desa Way Laga Kecamatan Panjang Bandar Lampung. Kebun yang diteliti adalah milik petani setempat (Bapak Sugiwo). Luas kebun yang diteliti adalah $4500 \mathrm{~m}^{2}$. Penentuan pohon sampel dan buah sampel dilakukan pada tanggal 14 dan 17 April 2014. Panen dilakukan secara bertahap dari tanggal 10 juli sampai 19 September 2014.

Alat yang digunakan dalam penelitian ini adalah kantung plastik ukuran sedang $(30 \mathrm{~cm} \times 15 \mathrm{~cm})$ dan ukuran besar $(35 \mathrm{~cm} \times 20 \mathrm{~cm})$, kertas label, tali rapia, timbangan, paralon, meteran, dan karet gelang. Kantung plastik yang digunakan dilubangi pada bagian bawahnya. Paralon digunakan untuk merakit alat penyelubung buah (Gambar 1).

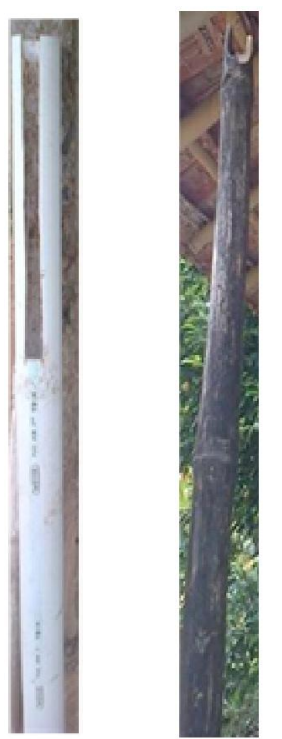

Gambar 1. Alat penyelubung buah kakao (kiri), bambu pendorong (kanan)

Alat yang digunakan untuk penyelubungan buah kakao terbuat dari pipa paralon yang berdiameter 1,5 inci dengan panjang 1 meter. Paralon yang telah diukur, pada salah satu sisinya diberi lubang secara vertikal (tegak) sepanjang $80 \mathrm{~cm}$ (Gambar 1).Setelah itu, kayu pendorong dibuat dari bambu kecil yang pada ujung atasnya dipotong membentuk huruf "v" (Gambar 1), untuk mendorong kantung-kantung plastik yang akan digunakan untuk menyelubungi buah kakao. Setelah alat siap, kantung plastik dipasang pada pipa paralon, kemudian diikat dengan karet pada bagian ujung kantung plastik. Kemudian ujung kantung plastik tersebut dilipat kearah bawah. Kantung plastik berikutnya dipasang lagi dan diatur sedemikian rupa sehingga kantung plastik tersusun pada peralatan tersebut sesuai kebutuhan dan kemampuan peralatan. Bahan yang digunakan dalam penelitian ini adalah tanaman kakao. Tanaman kakao yang digunakanberumur 7 tahun. Tanaman kakao yang digunakan terdiri atas dua jenis yaitu kakao dengan buah berwarna hijau dan merah.

Perlakuan yang digunakan pada penelitian ini terdiri atas penyelubungan buah dengan kantung plastik berukuran sedang ( $30 \mathrm{~cm} \times 15 \mathrm{~cm}, \mathrm{P} 1)$, penyelubungan buah dengan kantung plastik berukuran besar $(35 \mathrm{~cm} \mathrm{x}$ $20 \mathrm{~cm}, \mathrm{P} 2)$, dan tanpa penyelubungan buah atau kontrol (P0). Penelitian ini menggunakan 30 ulangan.

Pada penelitian ini, sampel terdiri atas pohon dan buah kakao. Jumlah pohon sampel yang digunakan sebanyak 30 pohon (digunakan sebagai ulangan). Penentuan pohon sampel dilakukan secara acak dari seluruh pohon pada kebun yang diamati. Seluruh pohon yang berpotensi sebagai pohon sampel (minimal memiliki 3 buah muda) diberi nomor pada batang pohon. Pada penelitian ini jumlah pohon yang berpotensi sebagai sampel sebanyak 57 pohon. Kemudian dipilih 30 pohon yang akan dijadikan sampel menggunakan angka acak. Adapun buah yang digunakan sebagai sampel pada pohon sampel adalah yang masih segar (tidak layu), dan maksimal berukuran $9 \mathrm{~cm}$.

Pada satu pohon sampel diambil tigabuah sampel secara acak, masing-masing untuk perlakuan penyelubungan buah dengan kantung plastikberukuran sedang ( $30 \mathrm{~cm} \times 15 \mathrm{~cm}, \mathrm{P} 1)$, penyelubungan buah dengan kantung plastik berukuran besar( $35 \mathrm{~cm} \times 20 \mathrm{~cm}, \mathrm{P} 2)$, dan tanpa penyelubungan atau kontrol (P0). Buah yang telah dipilih sebagai sampel kemudian diberi label yang sesuai (P0, P1, atau P2). Bahan label yang digunakan dalam penelitian ini adalah plastikmika yang berbeda warna untuk setiap perlakuan. Label tersebut berisi tentang perlakuan dan nomor ulangan yang ditulis menggunakan spidol permanen.

Variabel utama yang diamati adalah keterjadian serangan Helopeltis sp. dan keparahan serangan Helopeltis sp. pada buah kakao. Keterjadian serangan hama Helopeltis sp. dihitung dengan rumus Dinata et al. (2012) sebagai berikut.

$$
\mathrm{I}=\frac{\mathrm{n}}{\mathrm{N}} \times 100 \%
$$

\section{Keterangan:}

$\mathrm{I}=$ persentase keterjadian serangan,

$\mathrm{n}=$ jumlah buah terserang

$\mathrm{N}=$ jumlah buah yang diamati (30 buah). 
Keparahan serangan hama Helopeltis sp. dihitung dengan cara mempersentasekan serangan yang ditimbulkan. Buah-buah kakao sampel dipotret dan hasil potret (foto) permukaan buah (gejala serangan) tersebut dipersentasekan. Penentuan keparahan serangan dilakukan pada saat setelah penyelubungan atau ketika panen.

Variabel lain yang diamati pada penelitian ini adalah berat kering biji. Berat kering biji diamati ketika panen. Berat kering biji diukur dengan standar petani, yaitu dengan menimbang biji kakao yang sudah dikeringkan. Data yang didapat digunakan sebagaipenunjang penelitian.

Data pada awalnya dianalisis dengan analisis ragam. Namun demikian, asumsi homogenitas ragam tampak tidak terpenuhi. Setelah data ditransformasi menggunakan transformasi arc - sinus pun asumsi tersebut juga tidak terpenuhi. Oleh karena itu kemudian data dianalisis secara deskriptif menggunakan histogram.

\section{HASIL DAN PEMBAHASAN}

Hasil penelitian menunjukkan bahwa penyelubungan buah mampu menurunkan serangan hama Helopeltis sp. Pada buah yang tidak diselubungi terdapat relatif banyak bekas tusukan Helopeltis sp. berupa bercak-bercak berwarna coklat kehitaman, sedangkan pada buah yang diselubungi tidak terdapat atau sedikit terdapat bercak-bercak tersebut.

Keterjadian serangan hamaHelopeltis sp.. Penyelubungan buah terlihat mampu menekan keterjadian serangan hama Helopeltis sp. Keterjadian serangan pada buah yang tidak diselubungi dengan kantung plastik (P0) mencapai 83,3\%. Keterjadian serangan hama itu pada buah yang diselubungi dengan kantung plastik berukuran sedang $(30 \mathrm{~cm} \times 15 \mathrm{~cm}, \mathrm{P} 1)$ dan kantung plastik berukuran besar $(35 \mathrm{~cm} \times 20 \mathrm{~cm}$, P2) berturut-turut adalah $36,7 \%$ dan 23,3\% (Gambar 2).

Keparahan serangan hama Helopeltis sp. Hasil penelitian menunjukkan bahwa penyelubungan buah kakao dengan kantung plastik juga mampu menurunkan keparahan serangan hama Helopeltis sp. Pada buah yang tidak diselubungi (P0) keparahan serangan hama Helopeltis sp. yang terjadi sebesar 19,3\%. Setelah buah diselubungi dengan kantung plastik berukuran sedang ( $30 \mathrm{~cm} \times 15 \mathrm{~cm}, \mathrm{P} 1)$ dan berukuran besar $(35 \mathrm{~cm} \times 20 \mathrm{~cm}, \mathrm{P} 2)$ berturut-turut adalah 3,9\% dan 2,4\% (Gambar 3).

Penyelubungan buah kakao dengan kantung plastik tampaknya dapat mengendalikan serangan hama Helopeltis sp. Penyelubungan ini dapat melindungi buah dari serangan Helopeltis sp., yaitu mencegah Helopeltis sp. menghisap buah tersebut. Hal ini menunjukkan bahwa penyelubungan buah kakao efektif mengendalikan hama Helopeltis sp. Menurut Mustafa (2005) metode penyelubungan buah kakao jauh lebih efektif untuk mengendalikan hama dibandingkan dengan pengendalian secara kimiawi.

Berdasarkan hasil penelitian terlihat bahwa penyelubungan buah dengan kantung plastik berukuran besar dapat menekan serangan hama Helopeltis sp. Penyelubungan buah menggunakan kantung plastik berukuran besar $(35 \mathrm{~cm} \times 20 \mathrm{~cm})$ dapat menutupi

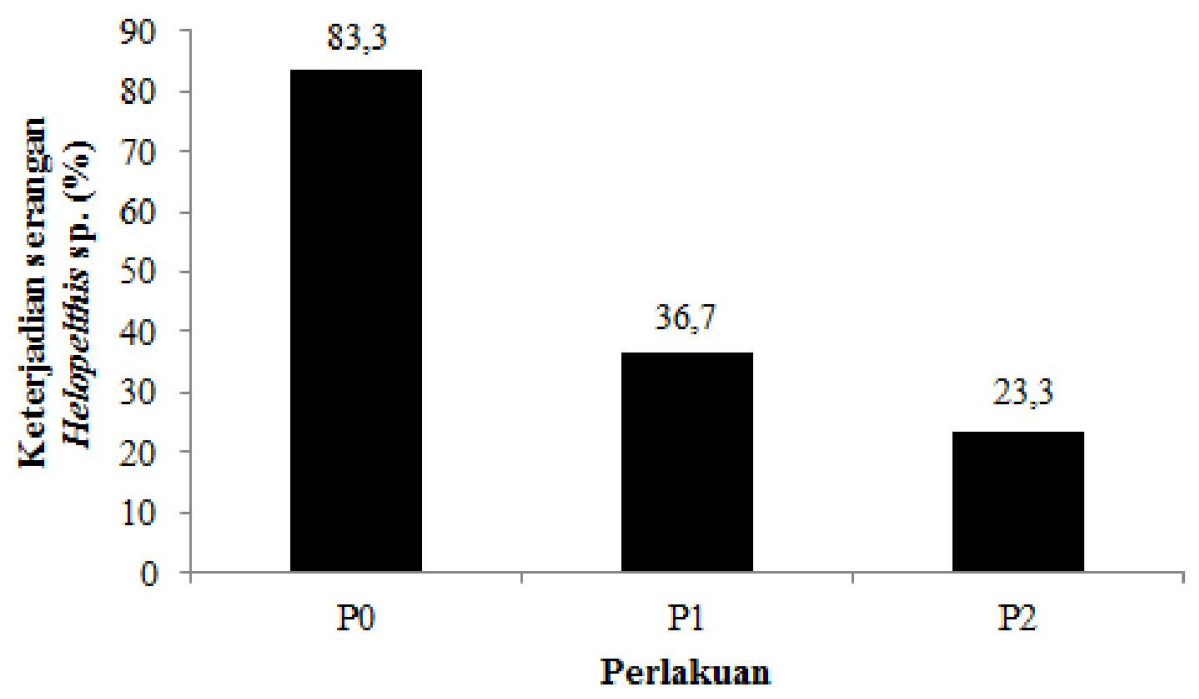

Gambar 2. Diagram batang keterjadian serangan hama Helopeltis sp. $\mathrm{P} 0=$ tanpa penyelubungan buah, $\mathrm{P} 1=$ penyelubungan buah dnegna kantong plastik $(30 \mathrm{~cm} \times 15 \mathrm{~cm}), \mathrm{P} 2=$ penyelubungan buah dnegna kantong plastik (35 cmx $20 \mathrm{~cm})$ 


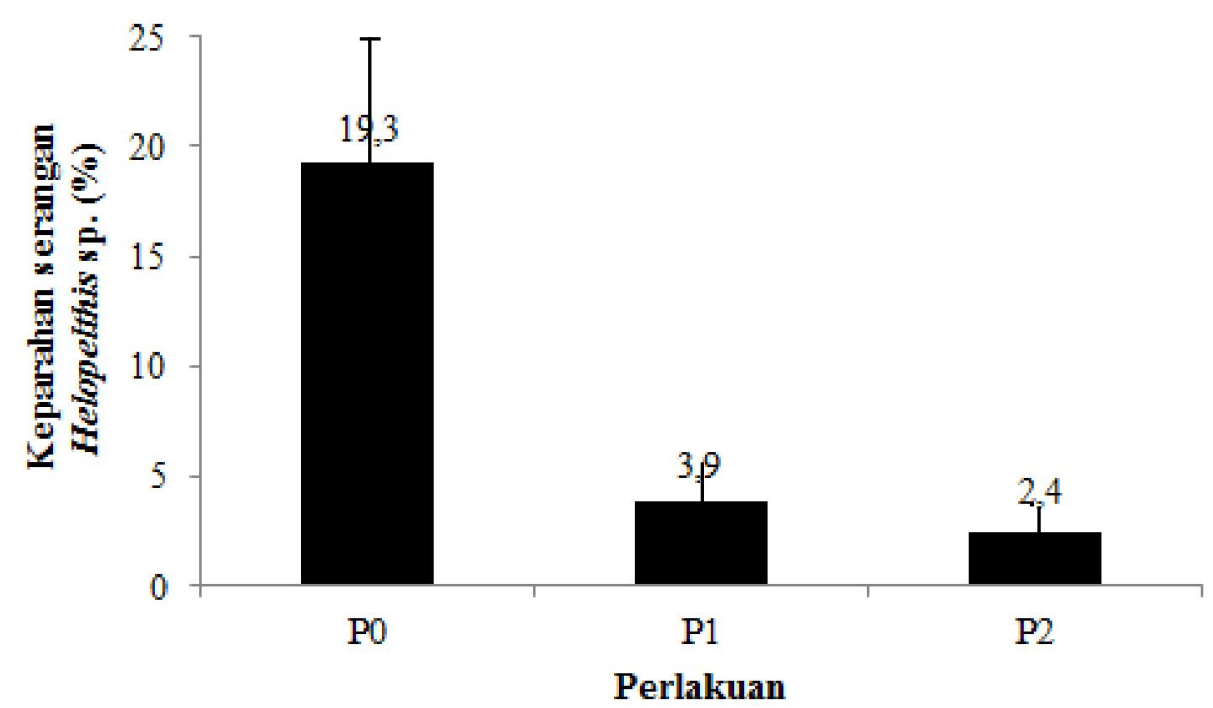

Gambar 3. Diagram batang keparahan serangan hama Helopeltis sp. Bar $=$ galat baku. $\mathrm{P} 0=$ tanpa penyelubungan buah, $\mathrm{P} 1=$ penyelubungan buah dnegna kantong plastik $(30 \mathrm{~cm} \mathrm{x15} \mathrm{cm}), \mathrm{P} 2=$ penyelubungan buah dnegna kantong plastik $(35 \mathrm{cmx} 20 \mathrm{~cm})$

seluruh bagian buah kakao, sehingga dapat mencegah hama Helopeltis sp. menghisap buah kakao tersebut. Pada penyelubungan buah menggunakan kantung plastik berukuran sedang $(30 \mathrm{~cm} \times 15 \mathrm{~cm})$, masih terjadi serangan Helopeltis sp. pada ujung beberapa buah yang tidak terselubungi.Namun dalam penelitian ini efektivitas penggunaan kantung plastik berukuran besar tampak tidak lebih baik daripada penggunaan kantung plastik berukuran sedang.Hal ini disebabkan ukuran kantung plastik yang digunakan memiliki ukuran yang tidak berbeda jauh, yaitu menggunakan kantung plastik berukuran besar versus sedang. Jika ukuran kantung plastik yang digunakan besar versus kecil, maka bedaefektivitasnya diperkirakan akan lebih jelas.

Berat Kering Biji. Hasil penelitian menunjukkan bahwa berat kering biji tidak berbeda nyata pada setiap perlakuan. Pada buah yang tidak diselubungi (kontrol, P0) berat kering biji kakao sebesar 8,65 g. Pada buah yang diselubungi dengan kantung plastik berukuran sedang ( $30 \mathrm{~cm}$ x $15 \mathrm{~cm}, \mathrm{P} 1)$ berat kering biji buah kakao sebesar 33,3 g. Sedangkan buah yang diselubungi dengan kantung plastik berukuran besar $(35 \mathrm{~cm} \times 20$ $\mathrm{cm}, \mathrm{P} 2)$ berat kering biji buah kakao sebesar 28,61 $\mathrm{g}$ (Gambar 4).

Penyelubungan buah muda dengan kantung plastik tampak mempengaruhi berat kering biji kakao.Berat kering biji terlihat tidak berbeda antara kontrol dan buah yang diselubungi.Biji kering pada buah yang diselubungi tampak lebih berat dari pada kontrol. Hal ini diperkirakan terkait dengan serangan hamaHelopeltis sp. lebih tinggi pada kontrol (Gambar 3 dan Gambar 4), sehingga buah menjadi busuk (Soetejo, 1983 dalam Mahdona, 2009).
Selain itu, buah yang tidak diselubungi juga tampak terserang berat oleh hama penggerek buah yang mengakibatkan biji saling melekat, sehingga produksi biji berkurang.

Pada penelitian ini keterjadian serangan Helopeltis sp. pada buah kakao berkulit merah terlihat lebih rendah dibandingkan dengan serangan pada buah kakao berkulit hijau. Keterjadian serangan pada buah kakao berkulit hijau yang tidak diselubungi kantung plastik (P0) sebesar 93,3, sedangkan keterjadian serangan pada buah kakao berkulit merah yang tidak diselubungi kantung plastik (P0) sebesar 73,3\%. Begitu pula dengan keparahan serangan pada buah kakao berkulit merah yang tidak diselubungi kantung plastik (P0) sebesar $11,4 \%$, dan pada buah kakao berkulit hijau yang tidak diselubungi kantung plastik (P0) keparahan serangan yang terjadi sebesar $13,2 \%$. Biasanya warna tertentu dapat menentukan hama untuk mengetahui apakah tanaman tersebut cocok atau tidak menjadi tanaman inangnya.

Menurut Pertiwi dkk. (2013) respon hama terhadap warna merah berkaitan dengan panjang gelombang cahaya yang dipantulkan. Warna merah pada kulit kakao dapat menolak serangan hama Helopeltis sp. Menurut Miller dkk. (1987 dalam Pertiwi dkk., 2013), panjang gelombang cahaya pada spektrum warna merah adalah $630-760 \mathrm{~nm}$. Sedangkan serangga hanya mampu memberikan respon terhadap cahaya dengan panjang gelombang antara 300-400 $\mathrm{m \mu}$ (warna mendekati ultra violet) sampai 600-650 $\mathrm{m \mu}$ (warna jingga). Diantara beberapa warna spektrum cahaya tersebut, ada dua yang menghasilkan respon paling tinggi 


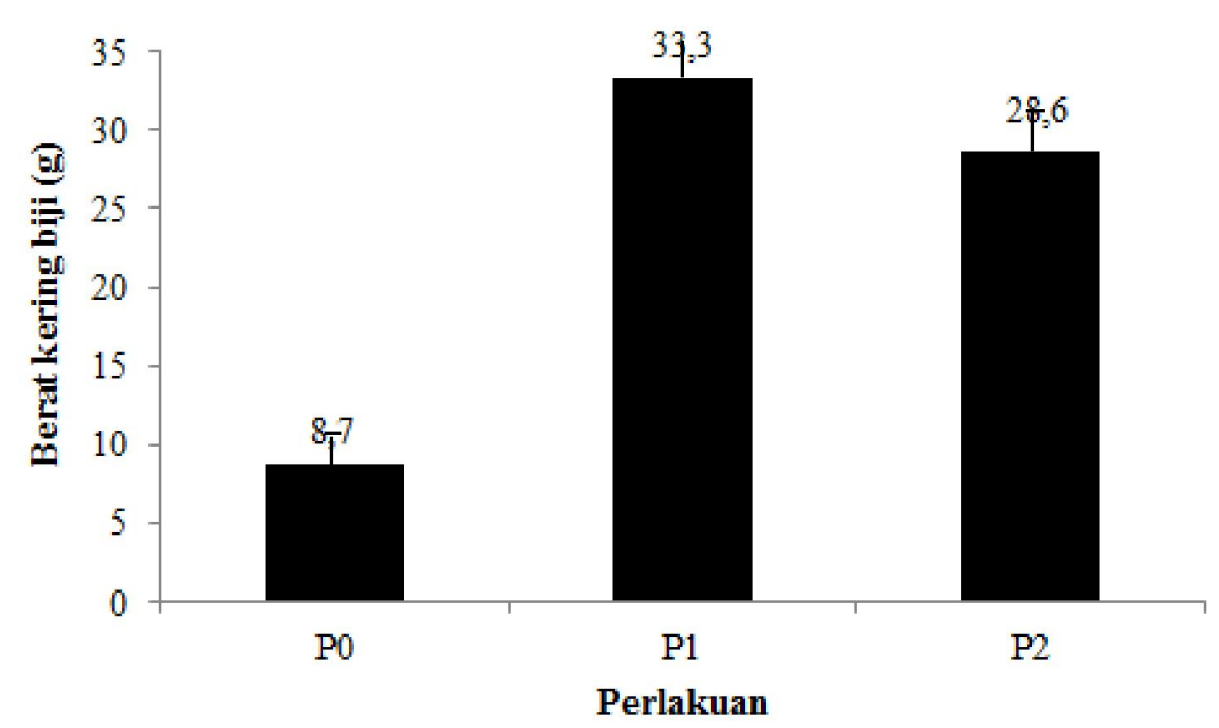

Gambar 4. Diagram batang berat kering biji; $\mathrm{Bar}=$ galat baku. $\mathrm{P} 0=$ tanpa penyelubungan buah, $\mathrm{P} 1=$ penyelubungan buah dnegna kantong plastik $(30 \mathrm{~cm} \times 15 \mathrm{~cm}), \mathrm{P} 2=$ penyelubungan buah dnegna kantong plastik $(35 \mathrm{cmx}$ $20 \mathrm{~cm})$

pada serangga yaitu cahaya mendekati ultraviolet (350 $\mathrm{m} \mu)$ dan hijau kebiruan $(500 \mathrm{~m} \mu)$ (Sodiq, 2009).

\section{KESIMPULAN}

Kesimpulan yang diperoleh dari penelitian ini adalah penyelubungan buah kakao menggunakan kantung plastik efektif mengurangi keterjadian dan keparahan serangan Helopeltis sp. namun efektivitas penggunaan kantung plastik berukuran relatif besar ( 35 $\mathrm{cm} \times 20 \mathrm{~cm}$ ) tampak tidak berbeda dengan efektivitas penggunaan kantung plastik berukuran sedang $(30 \mathrm{~cm}$ x $15 \mathrm{~cm})$.

\section{DAFTAR PUSTAKA}

Dhalimi, A. 2012.Kajian Inovasi Teknologi Spesifik Lokasi Mendukung Sistem dan Model Pengembangan Good agricultural practice di Wilayah Gernas Kakao. Laporan perkembangan kegiatan termin I dalam Program Insentif peningkatan kemampuan peneliti dan perekayasa.Balai Besar Pengkajian dan Pengembangan Teknologi Pertanian. Bogor. $11 \mathrm{hlm}$.

Dinata, K., Afrizon, Siti R. dan Herlena B. A. 2012. Permasalahan dan Solusi Pengendalian Hama PBK pada Perkebunan Kakao Rakyat di Desa Suro Bali Kabupaten Kepahiang.http:// bengkulu.litbang.deptan.go.id/ind/images/ dokumen/peternakan/kus-bptpbkl.pdf. diakses pada tanggal 23 Agustus 2014.

Mustafa, B. 2005. Kajian Penyelubungan Buah Muda Kakao Sebagai Suatu Metode Pengendalian Penggerek Buah Kakao (PBK) Conopomorpha cramerellaSnellen (Lepidoptera Gracillariidae).Hlm 23 - 35 Dalam:Prosiding Seminar Ilmiah dan Pertemuan Tahunan PEI dan PFI XVI Komda SulSel. Saenong, M.S., Baharuddin, T. Kuswinanti, I. D. Daut, dan N. Agus (ed.). Balai Tanaman Serealia. Maros, 22 November 2005.

Mahdona, N. 2009. Tingkat Serangan Hama Kepik Penghisap Buah (Helopeltis spp) (Hemiptera : Miridae) pada Tanaman Kakao (Theobromacacao L.) di Dataran Rendah dan Tinggi Sumatra Barat. (Skripsi). Universitas Andalas. Padang.

Nurmansyah.2011. Efektivitas Serai Wangi Terhadap Hama Pengisap Buah Kakao HelopeltisAntonii.Bul. Littro 22 (2) : 205 - 213.

Pertiwi, E. D., L. Asrul, \& S. Baja.2013. Karakteristik Fenotipe Buah Kakao Rentan Terhadap Serangan Hama Penggerek Buah Kakao (Conopomorpha Cramerella Snellen).http://pasca.unhas.ac.id/ jurnal/files/3c233cdc9253a6el1ff948719fe 6a028. pdf. diakses pada tanggal 3 Agustus 2014. 
Siswanto \& E. Karmawati. 2012. Pengendalian Hama Utama Kakao (Conopomorpha cramerella dan Helopeltis spp.) dengan Pestisida Nabati dan Agens Hayati. Perspektif 11 (2) : 103 - 112.
Sodiq, M. 2009. Ketahahan Tanaman Terhadap Hama.http://digilib.upnjatim.ac.id/ files/disk1/ 1/jiptupn-gdl-mochsodiqp-50-2-ketahanan.pdf. diakses pada tanggal 26 November 2014. 